\title{
Validations of the daily periodicity of increment deposition in rocky intertidal fish otoliths of the south-eastern Pacific Ocean
}

\author{
Validación de la periodicidad diaria de los incrementos en otolitos \\ de peces intermareales del Pacífico sudoriental

\section{Lidia Mansur'1, Daniela Catalán', Guido Plaza², Mauricio F. Landaeta ${ }^{3}$ and F. Patricio Ojeda ${ }^{1}$}

\begin{abstract}
${ }^{1}$ Departamento de Ecología, Pontificia Universidad Católica de Chile, Alameda 340, Santiago de Chile, Chile. lmansur@bio.puc.cl

${ }^{2}$ Escuela de Ciencias del Mar, Facultad de Recursos Naturales, Pontificia Universidad Católica de Valparaíso, Avenida Altamirano 1480, Casilla 1020, Valparaíso, Chile

${ }^{3}$ Laboratorio de Ictioplancton (LABITI), Facultad de Ciencias del Mar y de Recursos Naturales, Universidad de Valparaíso, Avenida Borgoño 16344, Reñaca, Viña del Mar, Chile

Abstract.- Daily deposition of otolith increments was validated for juveniles of 8 intertidal fish species in central Chile, Helcogrammoides chilensis, Helcogrammoides cunninghami (Tripterygiidae), Auchenionchus microcirrhis, Auchenionchus crinitus (Labrisomidae), Hypsoblennius sordidus (Blenniidae), Gobiesox marmoratus, Sicyaces sanguineus (Gobiesocidae) and Myxodes viridis (Clinidae). Validation was performed by Alizarin Red-S labelling followed by 6 days of growth.
\end{abstract}

Key words: Otolith daily increments, alizarin red S, intertidal fishes

\section{INTRODUCTION}

The increment patterns of otoliths have permitted great progress in studies on the growth dynamics of fish. In addition to age and growth, fish otoliths may also record life history events such as metamorphosis, settlement and migration (Victor 1982, Sponaugle \& Cowen 1994, Jenkins et al. 1996, Wilson \& McCormick 1997, Thorrold et al. 2001). Age estimates can be obtained by the enumeration of growth increments observed in the otoliths. These increments can be deposited annually (e.g., Fowler 1990), daily (e.g., Campana \& Neilson 1982, Schmitt 1984, Iglesias et al. 1997), or even sub-daily (e.g., Pannella 1971, Campana \& Neilson 1982).

Because of the potential variation in the temporal pattern of increment formation, it is important to validate otolith increment periodicity when using otoliths to age fishes. The experimental manipulation of temperature, light or food ration can produce a natural structural mark in the otolith which may be used in age validation (e.g., Victor 1982). However, a chemically induced mark is preferable because it is more easily distinguished from naturally occurring variation in increment structure. Therefore, validation of increment periodicity is commonly achieved by inducing a mark in the otolith, then sacrificing the fish after a number of days, months or years. The number of growth increments deposited between the induced artificial mark and the otolith edge is then compared to the known time period the fish was alive since mark induction (Hernaman et al. 2000).

Fluorescent chemicals such as tetracycline and calcein have been widely used to mark otoliths of species from many families of tropical and temperate fishes (e.g., Schmitt 1984, Monaghan 1993, Wilson \& McCormik 1997). Recently Alizarin Red S has been used as an effective chemical marker in a number of studies (Skov 2001, Fitzpatrick et al. 2010). This fluorescent compound is assimilated and incorporated into the calcareous structure of the otoliths and can be detected by epifluorescence microscopy. Used in combination with light microscopy, the staining technique reveals the number of rings deposited after they have been marked (Campana 2001).

The central coast of Chile comprises a large diversity of fish, including the $44 \%$ of the all endemic species recorded in southeast Pacific (Ojeda et al. 2000). Typically, fish assemblages observed in rocky intertidal zones are characterized by resident and transient species. While residents remain in the intertidal area after recruitment, transient species migrate to the subtidal once they reach a certain body size (Varas \& Ojeda 1990, Muñoz \& Ojeda 
1997). Numerous studies have focused on the biology and ecology of the most conspicuous species found in the rocky intertidal, primarily on the juvenile and adult phases of life (Varas \& Ojeda 1990, Cáceres \& Ojeda 2000, Fariña et al. 2000, Muñoz \& Ojeda 2000, Williams \& Springer 2001, Hernández-Miranda et al. 2009, HernándezMiranda \& Ojeda 2006, Pulgar et al. 2006). However, in recent years, research has addressed pre-recruitment biology and dynamics (Plaza-Pasten et al. 2003, Hernández-Miranda et al. 2009, Palacios-Fuentes et al. 2012, Contreras et al. 2013). Most of the research conducted on pre-recruits heavily relied on the information obtained from reading otoliths, usually assuming the number of observed rings corresponded with a daily frequency of deposition. To confirm this assumption, the current study aimed to validate the periodicity of increment deposition in post-settlement juveniles of 8 intertidal fish species of central Chile using Alizarin Red S as the fluorescent marker.

\section{Materials AND METHODS}

Young-of-the-year (YOY) of triplefins Helcogrammoides chilensis, Helcogrammoides cunninghami (Tripterygiidae), labrisomids Auchenionchus microcirrhis, Auchenionchus crinitus (Labrisomidae), blenny Hypsoblennius sordidus (Blenniidae), clingfishes Gobiesox marmoratus, Sicyases sanguineus (Gobiesocidae) and clinid Myxodes viridis (Clinidae) were collected from rocky intertidal pools at 3 localities separated by approximately $10 \mathrm{~km}$ of sandy beaches along the central Chilean coast: Las Cruces (LC: $33^{\circ} 30^{\prime} \mathrm{S}$;

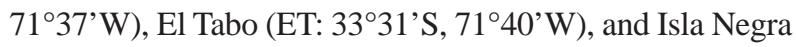
(IN: $33^{\circ} 24^{\prime}$ S, $71^{\circ} 43^{\prime} \mathrm{W}$ ). Fish were captured with hand nets aided by the use of $20 \%$ benzocaine (BZ-20) between April 2010 and December 2011. Captured YOY were placed in labelled plastic bags and transported to the laboratory, where total length (TL) was measured to the nearest $\mathrm{mm}$. The collected specimens (Table 1) were transferred to the laboratory in 'Estación Costera de Investigaciones Marinas' (ECIM). To acclimatize the fishes, they were kept in 15-L aquaria for 7 days under natural light photoperiod, with constantly aerated, circulating water, and fed ad libitum with TetraMarine Saltwater Flakes ${ }^{\circledR}$ food nutritional supplement on a daily basis.

The Alizarin Red S (LobaChemi $\left.{ }^{\circledR}\right)$ was dissolved in seawater in two 15-L tanks at a concentration of $150 \mathrm{mg} \mathrm{l}^{-1}$. The tanks remained strongly aerated to maintain the $\mathrm{pH}$ near 7. Individuals were kept in the Alizarine Red S tanks for $24 \mathrm{~h}$ before transferring them to small aquaria (5-L),

Table 1. Alizarin Red $S$ marking experiment. Survival during the experiment (\% sur.), number of analysed sagittae $(\mathrm{n})$, average total length in $\mathrm{mm}(T L \pm S D)$, number of rings/sagitta $(r \pm S D)$ ) and chi-square statistical results $\left(\chi^{2}\right)$, degrees of freedom (df), probability $(\boldsymbol{P})$ of the 8 species evaluated / Porcentaje de sobrevivencia resultante del experimento (\% sur.), número de sagitta analizados ( $n$ ), longitud total promedio de los individuos en milímetros $(T L \pm D E)$, número de anillos/sagitta $(r \pm D E)$ y resultados estadísticos chi-cuadrado $\left(\chi^{2}\right)$, grados de libertad (df), probabilidad $(P)$, de las 8 especies evaluadas

\begin{tabular}{lccccccc}
\hline Family/ Species & $\begin{array}{c}\% \\
\text { Survival }\end{array}$ & $\mathrm{n}$ & $\mathrm{TL}(\mathrm{mm})$ & $\mathrm{r}$ & $\chi^{2}$ & $\mathrm{df}$ & $P$ \\
\hline Labrisomidae & & & & & & & \\
$\quad$ A. crinitus & 81.81 & 9 & $75.11 \pm 17.17$ & $5.22 \pm 0.44$ & 1.17 & 8 & 0.997 \\
$\quad$ A. microcirrhis & 81.81 & 9 & $135.39 \pm 36.33$ & $5.22 \pm 0.44$ & 1.17 & 8 & 0.997 \\
$\begin{array}{l}\text { Tripterygiidae } \\
\text { H. chilensis }\end{array}$ & 88.63 & 15 & $37.60 \pm 12.40$ & $5.20 \pm 0.68$ & 2.67 & 14 & 0.999 \\
$\quad$ H. cunninghami & 83.33 & 5 & $32.17 \pm 2.96$ & $6.00 \pm 0.0$ & 0.21 & 4 & 0.977 \\
$\begin{array}{l}\text { Blenniidae } \\
\quad \text { H. sordidus }\end{array}$ & 87.18 & 15 & $38.50 \pm 5.95$ & $3.87 \pm 0.83$ & 13.00 & 18 & 0.527 \\
Clinidae & & & & & & & \\
$\quad$ M. viridis & 45.45 & 4 & $91.75 \pm 2.30$ & $4.75 \pm 0.50$ & 1.17 & 3 & 0.761 \\
Gobiesocidae & & & & & & & \\
$\quad$ G. marmoratus & 87.50 & 7 & $40.91 \pm 9.47$ & $4.71 \pm 0.49$ & 2.17 & 6 & 0.904 \\
$\quad$ S. sanguineus & 14.29 & 5 & $24 \pm 5.21$ & $4.60 \pm 0.89$ & 2.17 & 4 & 0.705 \\
\hline
\end{tabular}




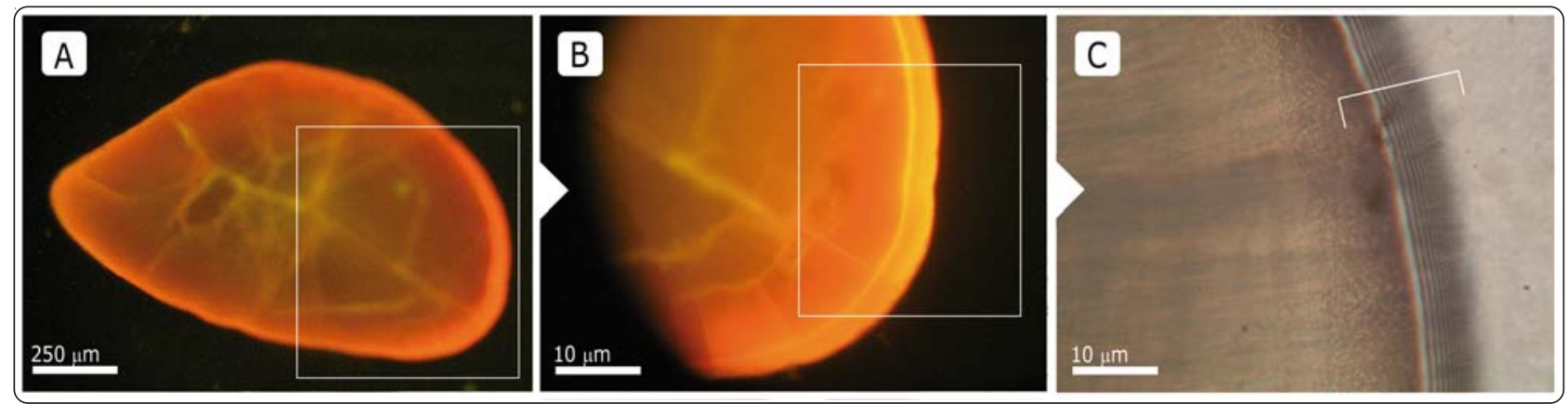

Figure 1. Photographs of sagittae used to validate the daily periodicity of otolith increments in $\boldsymbol{H}$. chilensis. A-B: fluorescence microscope, C: light microscope / Fotografías del otolito sagitta de $H$. chilensis utilizado para validar la periodicidad de los incrementos. A-B: Imágenes en microscopio de fluorescencia, C: Imagen en microscopio óptico

with constantly aerated, circulating water. Each tank had five fish that were fed ad libitum for 6 days. After the sixth day, the fish were subject to fasting one day, followed by the second 24-h staining treatment with Alizarin Red-S was then carried out. The second staining was performed in order to have a specific fluorescent ring and test the hypothesis that if the dynamics of deposition is daily, 6 rings must be found between the 2 fluorescent rings.

The surviving fish were sacrificed with BZ-20, measured and fixed in $96 \%$ ethanol. Sagitta, asteriscus and lapillus otoliths were removed and kept in bidistilled water. The sagitta otoliths were mounted on slides with epoxy resin, polished with 30 ìm and 1 ìm grit paper and photographed with white light and UV under an epifluorescence microscope (Nikon ${ }^{\circledR}$ Eclipse E4000, blue filter Nikon B-2A). Images were obtained with an Olympus ${ }^{\circledR}$ Camedia C-5050 digital camera. The numbers of rings in the images were counted between the Alizarine Red S marks with the aid of the Image Pro-Express ${ }^{\circledR}$ Software, version 4.5, 2002 (Media Cybernetics) (Fig. 1). The number of observed rings observed was compared with the expected number of rings (6) and analyzed with the chi square test using STATISTICA 6.0 (Zar 1999).

\section{RESULTS AND DISCUSSION}

Survival rates to the Alizarin Red S treatment were high for six of the eight species under study ( $\geq 85 \%)$. The lowest survival rates were recorded for $M$. viridis (45\%) and S. sanguineus (15\%; Table 1). A fluorescent mark was clearly visible under UV light in the sagittae of all fishes. Daily increments following the fluorescent mark were clearly discernible in all of the sagittae examined. There was a generally good agreement between the expected and observed numbers of daily increments between the Alizarin Red S marks for all species (Table 1).

The present research confirmed that primary increments in otoliths of YOY of 8 intertidal fish species studied were deposited on a daily basis. The results are consistent with what is known to date. The daily periodicity of otolith increments has been confirmed in the larvae and juveniles of many teleost fishes (Hernaman et al. 2000, Joh et al. 2005, Parkinson et al. 2012) including some intertidal species (Hernaman et al. 2000) including 4 species of New Zealand intertidal triplefins that were validated using injected tetracycline (Kohn \& Clements 2011). In the current research, Alizarin Red $S$ appeared as clear fluorescent marks in all of the YOY analyzed, which agrees with recent studies demonstrating this compound to be a very effective chemical marker for validating growth bands in larval, juvenile and adult teleost fishes. It had a similar performance to alizarin complexone, calcine and other tetracycline-derived markers (Bashey 2004, Meisfjord et al. 2006, Crook et al. 2007, Liu et al. 2009, Fitzpatrick et al. 2010).

Finally, this work demonstrates a simple technique to validate the increment patterns of otoliths in pre-recruits of the most common species inhabiting the rocky intertidal coast of central Chile. Moreover, our research validates results of previous studies and provides a basis for future investigations of growth of pre-recruits in intertidal fish assemblage in central Chile.

\section{ACKNowledgments}

We would like to thank Diego J. Mansur for his assistance with images. This study was funded by FONDECYT grant 1100424 awarded to F. P. Ojeda. L. Mansur is currently supported by a CONICYT Doctoral fellowship for Latin American students. 


\section{LITERATURE CITED}

Bashey F. 2004. A comparison of the suitability of alizarin red $\mathrm{S}$ and calcein for inducing a nonlethally detectable mark in juvenile guppies. Transactions of the American Fisheries Society 133: 1516-1523.

Cáceres CW \& FP Ojeda. 2000. Patrones de forrajeo en dos especies de peces intermareales herbívoros de las costas de Chile: efecto de la abundancia y composición química del alimento. Revista Chilena de Historia Natural 73: 253-260.

Campana SE. 2001. Accuracy, precision and quality control in age determination, including a review of the use and abuse of age validation methods. Journal of Fish Biology 59: 197242.

Campana SR \& JD Neilson. 1982. Daily growth increments in otoliths of starry flounder (Platichthys stellatus) and the influence of some environmental variables in their production. Canadian Journal of Fisheries and Aquatic Sciences 39: 937-942.

Contreras JE, MF Landaeta, G Plaza, FP Ojeda \& CA Bustos. 2013. The contrasting hatching patterns and larval growth of two sympatric clingfishes inferred by otolith microstructure analysis. Marine and Freshwater Research 64: 157-167.

Crook DA, D O'Mahony, BM Gillanders, AR Munro \& AC Sanger. 2007. Production of external fluorescent marks on golden perch fingerlings through osmotic induction marking with alizarin red S. North American Journal of Fisheries Management 27: 670-675.

Fariña JM, M Aldana, F Ogalde \& FP Ojeda. 2000. Ecología trófica de Girella laevifrons (Pisces: Kyphosidae) en zonas intermareales rocosas del norte de Chile afectadas y no afectadas por contaminantes derivados de la minería del cobre. Revista Chilena de Historia Natural 73: 113-124.

Fitzpatrick MP, AG Jeffs \& BJ Dunphy. 2010. Identification of the optimal fluorochrome for marking larvae of the pulmonate limpet Siphonaria australis. Journal of Shellfish Research 29: 941-944.

Hernaman V, PL Munday \& ML Schlappy. 2000. Validation of otolith growth-increment periodicity in tropical gobies. Marine Biology 137: 715-756.

Hernández-Miranda E \& FP Ojeda. 2006. Inter-annual variability of somatic growth rate and mortality of coastal fishes off central Chile: an ENSO driven process? Marine Biology 149: 925-936.

Hernández-Miranda E, R Veas, CV Espinoza, SR Thorrold \& FP Ojeda. 2009. The use of otoliths and larval abundance for studying the spatial ecology of the blenny Scartichthys viridis (Valenciennes, 1836) in coastal central Chile. Revista de Biología Marina y Oceanografía 44: 619-633.

Iglesias M, EB Brothers \& B Morales-Nin. 1997. Validation of daily increment deposition in otoliths. Age and growth determination of Aphia minuta (Pisces: Gobiidae) from the northwest Mediterranean. Marine Biology 129: 279-287.
Jenkins GP, MJ Wheatley \& AGB Poore. 1996. Spatial variation in recruitment, growth and feeding of postsettlement King George whiting, Sillaginoides punctata, associated with seagrass beds Port Philip Bay, Australia. Canadian Journal of Fisheries and Aquatic Science 53: 350359.

Joh M, T Takatsu, M Nakaya, T Higashitani \& T Takahashi. 2005. Otolith microstructure and daily increment validation of marbled sole (Pseudopleuronectes yokohamae). Marine Biology 147: 59-69.

Kohn YY \& KD Clements. 2011. Pelagic larval duration and population connectivity in New Zealand triplefin fishes (Tripterygiidae). Environmental Biology of Fishes 91: 275286.

Liu Q, XM Zhang, PD Zhang \& SA Nwafili. 2009. The use of alizarin red $\mathrm{S}$ and alizarin complexone for immersion marking Japanese flounder Paralichthys olivaceus. Fisheries Research 98: 67-74.

Lou DC. 1992. Validation of annual growth bands in the otolith of tropical parrotfishes (Scarus schlegeli Bleeker). Journal of Fish Biology 41: 775-790.

Meisfjord J, F Midtoy \& A Folkvord. 2006. Validation of daily increment deposition in otoliths of juvenile Limnothrissa miodon (Clupeidae). Journal of Fish Biology 69: 845-1848.

Monaghan JP. 1993. Comparison of calcein and tetracycline as chemical markers in summer flounder. Transactions of the American Fisheries Society 122: 298-301.

Muñoz AA \& FP Ojeda. 2000. Ontogenetic changes in the diet of the temperate marine herbivorous fish Scartichthys viridis in a rocky intertidal zone in central Chile. Journal of Fish Biology 56: 986-998.

Palacios-Fuentes P, MF Landaeta, G Muñoz, G Plaza \& FP Ojeda. 2012. The effects of a parasitic copepod on the recent larval growth of a fish inhabiting rocky coasts. Parasitology Research 111: 1661-1671.

Pannella G. 1971. Fish otoliths: Daily growth layers and periodical patterns. Science 173: 1124-1127.

Parkinson KL, DJ Booth \& JE Lee. 2012. Validation of otolith daily increment formation for two temperate syngnathid fishes: the pipefishes Stigmatopora argus and Stigmatopora nigra. Journal of Fish Biology 80: 698-704.

Plaza-Pasten G, S Katayama \& M Omori. 2003. Timing of parturition, planktonic duration, and settlement patterns of the black rockfish, Sebastes inermis. Environmental Biology of Fishes 68: 229-239.

Pulgar J, FP Ojeda \& F Bozinovic. 2006. Intraspecific geographic and seasonal physiological variability in an intertidal fish along a climatic gradient. Journal of Fish Biology 68: 975-981.

Schmitt PD. 1984. Marking growth increments in otoliths of larval and juvenile fish by immersion in tetracycline to examine the rate of increment formation. Fishery Bulletin 82: $237-242$. 
Skov C, P Gronkjaer \& C Nielsen. 2001. Marking pike fry otoliths with alizarin complexone and strontium: an evaluation of methods. Journal of Fish Biology 59: 745750.

Sponaugle S \& RK Cowen. 1994. Larval durations and recruitment patterns of two Caribbean gobies (Gobiidae): Contrasting early life histories in demersal spawners. Marine Biology 120: 133-143.

Varas E \& FP Ojeda. 1990. Intertidal fish assemblages of the central Chilean coast: Diversity, abundance and trophic patterns. Revista de Biología Marina 25: 59-70.
Victor BC. 1982. Daily otolith increment and recruitment in two coral reef wrasses, Thalassoma bisfasciatum and Helichoeres bivittatus. Marine Biology 71: 203-208.

Williams JT \& VG Springer. 2001. Review of the South American-Antarctic triplefin fish genus Helcogrammoides (Perciformes: Tripterygiidae). Revista de Biología Tropical 49: 117-123.

Wilson DT \& MI McCormick. 1997. Spatial and temporal settlement-marks in otoliths of tropical reef fishes. Marine Ecology Progress Series 153: 259-271.

Zar JH. 1999. Biostatistical analysis, 662 pp. Prentice Hall, Englewood Cliffs.

Received 25 March 2013 and accepted 25 July 2013

Editor: Claudia Bustos D. 